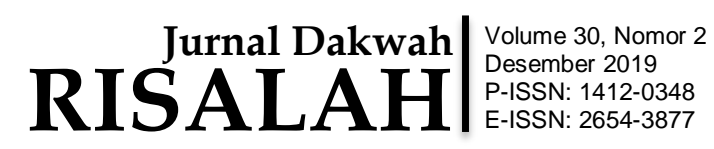

DOI: $10.24014 /$ jdr.v30i2.7532

\title{
PANDANGAN FORUM KERUKUNAN UMAT BERAGAMA MENGENAI MAKNA TOLERANSI ANTARUMAT BERAGAMA DI JAWA BARAT
}

\author{
Latifah $^{1}$, Achwan Noorlistyo Adi ${ }^{2}$, Adila Afifah ${ }^{3}$ \\ ${ }^{1,2,3}$ Universitas Putera Batam \\ Email: latifah.2588@gmail.com
}

\section{Kata kunci}

konflik antaragama, intoleransi, FKUB

\section{Keywords}

interfaith conflict, intolerance, FKUB

\begin{abstract}
Abstrak
Penelitian ini mengkaji bagaimana pandangan FKUB (Forum Kerukunan Umat Beragama) Jawa Barat mengenai makna toleransi terkait isu intoleransi di Jawa Barat. Pemberitaan di media massa tentang isu intoleransi mengenai pendirian gereja yang terjadi di Jawa Barat menjadi perhatian khusus. Hasil pengamatan sejumlah lembaga swadaya masyarakat beberapa tahun terakhir menempatkan Jawa Barat pada urutan pertama provinsi yang paling intoleran dengan meningkatnya aduan warga terkait isu intoleransi. Penelitian ini adalah penelitian kualitatif dengan metode penelitian studi kasus. Analisis kasus menggunakan teori Interaksi Simbolik. Hasil penelitian menemukan bahwa Jawa Barat salah satu Provinsi di Indonesia yang memiliki falsafah hidup yang toleran dan penganut ajaran agama Islam yang taat. FKUB memiliki peran penting dalam membantu menyelesaikan masalah yang berkaitan dengan isu maupun kasus intoleransi di Jawa Barat sebagai wadah dialog lintas agama. Permasalahan yang terjadi di Provinsi Jawa Barat adalah adanya kesalahpahaman dan kecurangan dalam mendirikan rumah ibadah. Masyarakat Jawa Barat memiliki falsafah kerukunan yaitu Someah Hade kasemah, Caina herang laukna benang, Silih Asah Silih Asih Silih Asuh.
\end{abstract}

\begin{abstract}
This study aims to analyse how West Java FKUB (Forum Kerukunan Umat Beragama)'s view on the meaning of tolerance relates to intolerance issue in West Java. The coverage on intolerance issue in mass media, escpecially about church construction that occurred in West Java becomes wide concern. The observations of nongovernmental organizations in recent years showed West Java as the most intolerant province based on the increasing complaints of citizens related to intolerance. This research is qualitative research using case study method. In analysing the case, the researcher used interactionism symbolic theory. The results of this research found that West Java is one of the Provinces in Indonesia which has tolerant life philosophy and pious muslims in practicing Islamic religion. FKUB has an important role to solve the problems related to issues and cases of intolerance in West Java as a forum for interfaith dialogue. The problem di West Java was misundestanding and fraud in constructing churchs. Citizens of West Java has philosophy of tolerance, Someah Hade kasemah, Caina herang laukna benang, Silih Asah Silih Asih Silih Asuh.
\end{abstract}


Latifah, dkk

Pandangan Forum Kerukunan Umat Beragama

Mengenai Makna Toleransi Antarumat Beragama di Jawa Barat
Jurnal Dakwah Risalah Vol. 30 No. 2. Desember 2019: Hal 136-153

\section{Pendahuluan}

Bangsa Indonesia dikenal sebagai bangsa yang majemuk, ditandai dengan banyaknya etnis, suku, agama, bahasa, budaya, dan adat istiadat. Untuk persoalan agama, negara Indonesia bukanlah sebuah negara teokrasi, melainkan secara konstitusional negara mewajibkan warganya untuk memeluk satu dari agama-agama yang diakui eksistensinya sebagaimana tercantum dalam pasal 29 ayat (1) dan (2) UUD 1945. Negara memberi kebebasan kepada penduduk untuk memilih salah satu agama yang telah ada di Indonesia yaitu agama Islam, Kristen Protestan, Kristen Katolik, Hindu, Budha, dan Konghuchu. Kenyataan ini dengan sendirinya memaksa negara untuk terlibat dalam menata kehidupan beragama.

Pada saat ini, umat beragama di Indonesia sering dihadapkan pada banyak permasalahan seperti yang pernah dialami sebelumnya. Perbedaan agama telah menjadi persoalan nyata yang ada dalam kehidupan umat beragama di Indonesia. Oleh karena itu, toleransi sangat dibutuhkan. Indonesia adalah negara yang sangat majemuk. Kebhinnekaan Indonesia itu terdapat dalam hampir seluruh aspek kehidupan, salah satunya adalah dalam hal agama. Republik Indonesia mengakui enam agama sebagai agama resmi yakni Islam, Katolik, Kristen Protestan, Hindu, Buddha, Kong $\mathrm{Hu} \mathrm{Chu}$ (Confucianism), dan juga aliran-aliran kepercayaan lainnya.

Ketentuan dalam pasal 29 UUD 1945 sangat penting artinya bagi agama-agama dan para pemeluknya karena telah memberi jaminan dan sarana keterlibatan umat di dalam mengisi dan memperkaya kehidupan berbangsa. Tiap pemeluk agama mendapatkan kesempatan untuk menjalankan agama dan menciptakan kehidupan beragama sesuai dengan ajaran agama masing-masing. Pengembangan agama dan kehidupan beragama tidak boleh menjurus ke arah tumbuhnya pemikiran dan pemahaman agama yang sempit karena hal ini akan menimbulkan konflik antaragama (Nisvilyah, 2013: 382).

Abdul Kadir mengatakan potensi integrasi akan terjadi apabila terdapat suasana keharmonisan hubungan dalam dinamika pergaulan terutama internal umat beragama dan antarumat beragama. Sebaliknya, potensi disintegrasi akan menjadi kenyataan apabila terdapat suasana saling curiga dan persaingan dalam dinamika baik internal umat beragama maupun antarumat beragama (Nisvilyah, 2013: 383).

Dengan adanya keberagaman masyarakat Indonesia, sering kali terjadi gesekangesekan. Akar dari gesekan-gesekan tersebut adalah perbedaan paham dalam cara pandang atau melihat sesuatu yang sangat kental dalam konteks agama. Toleransi dan intoleransi di Indonesia sangat dipengaruhi oleh hal itu. Achmad (dalam Digdoyo, 2018:43) melihat kenyataan masyarakat Indonesia memiliki tingkat keanekaragaman yang sangat kompleks termasuk di dalamnya menyangkut aliran kepercayaan. Masyarakat dengan berbagai keanekaragaman tersebut dikenal dengan istilah masyarakat multireligius. 
Pancasila dalam sila pertama, yaitu Ketuhanan Yang Maha Esa, menegaskan bertakwa kepada Tuhan menurut agama dan kepercayaan masing-masing adalah mutlak. Semua agama menghargai manusia maka dari itu semua umat beragama juga wajib saling menghargai. Dengan demikian, hubungan antarumat beragama yang berlainan akan terbina kerukunan hidup.

Menurut Profesor Jimly Asshiddiqie, Guru Besar Hukum Tata Negara Fakultas Hukum Universitas Indonesia, dalam hubungan antaragama banyak muncul kasus-kasus yang terjadi di masa reformasi ini, seperti pelanggaran terhadap para penganut Ahmadiyah, penganut Syi'ah, pelarangan terhadap pembangunan gereja, dan lain-lain (Asshiddiqie, 2013).

Jawa Barat adalah salah satu provinsi di Indonesia yang memiliki falsafah hidup yang toleran dengan penganut ajaran agama Islam yang taat. Akan tetapi, sejumlah riset menyebutkan bahwa kasus intoleransi paling banyak terjadi di Jawa Barat. Ini bertolak belakang dengan kultur masyarakat Sunda yang terkenal sangat toleran. Direktur TIC (The Islah Center) dan pengamat masalah terorisme, Mujahidin Nur, yang selama ini fokus terhadap isu-isu kerukunan beragama dan toleransi di Indonesia, mengatakan bahwa penelitian sejumlah LSM (Lembaga Swadaya Masyarakat) dalam beberapa tahun terakhir selalu menempatkan Jawa Barat pada urutan pertama provinsi yang paling intoleran.

Mujahidin mengatakan riset Setara Institute pada 2015 menempatkan Jawa Barat sebagai daerah yang paling banyak kasus pelanggaran hak atas KBB (Kebebasan Beragama dan Berkeyakinan) yakni sebanyak 44 kasus. Wahid Foundation juga menyebut selama 2015 telah terjadi 46 peristiwa pelanggaran Kebebasan Beragama dan Berkeyakinan di provinsi tersebut. Begitu juga berdasarkan hasil monitoring yang dilakukan oleh LBH (Lembaga Bantuan Hukum) Bandung sepanjang 2005 hingga 2011 terdapat 383 peristiwa tindak kekerasan dan intoleransi Kebebasan Beragama dan Berkeyakinan di Jawa Barat. Riset lain menyebutkan, sejak Januari 2013 sampai Januari 2014 terjadi sebanyak 76 peristiwa intoleransi, peristiwa tersebut terjadi di beberapa daerah di Jawa Barat seperti, Depok, Bekasi, Cianjur, Sukabumi, Cirebon, Bogor, dan Kabupaten Tasikmalaya. Dari data survei Wahid Foundation, provinsi Jawa Barat memasuki urutan pertama kasus intoleransi di Indonesia. Cukup memprihatinkan dari data survei yang telah dihimpun di kepolisian hampir 80 persen pelaku bom bunuh diri di Indonesia berasal dari Jawa Barat (www.tirto.id).

Masyarakat Sunda yang mempunyai kekayaan warisan leluhur, terkenal sebagai masyarakat yang ramah. Namun, dalam beberapa isu dan pemberitaan di media massa, Jawa Barat masuk sebagai salah satu provinsi dengan pemberitaan intoleransi yang terjadi. Sejumlah intoleransi yang dimaksud menurut TIC juga termasuk dalam bentuk 41 Perda yang dianggap diskriminatif dan intoleran dalam bentuk penyegelan, penutupan rumah ibadah, pembubaran ibadah kelompok atau agama tertentu, bahkan terjadinya kekerasan fisik (antaranews.com). 
Sepanjang sejarah peradaban manusia, agama dan keyakinan sebetulnya telah banyak memberikan sumbangsih besar bagi terciptanya perdamaian di muka bumi. Akan tetapi, karena pengetahuan dan kedewasaan masyarakat yang kurang mengenal toleransi, persoalan agama justru kerap menjadi pemicu lahirnya konflik horizontal (Wach dalam Digdoyo, 2018: 48). Membina toleransi umat beragama di Indonesia menjadi tanggung jawab sosial bersama dan merupakan budaya positif yang perlu dilanjutkan. Pandangan ini muncul dilatarbelakangi oleh seringnya terjadinya konflik hubungan antarumat beragama di Indonesia. Kehadiran dan peran FKUB sangat dirasa penting sebagai lembaga atau wadah yang memfasilitasi dialog antartokoh umat beragama, sehingga makna toleransi antarumat beragama di Indonesia, khususnya Jawa Barat sebagai provinsi yang disebut memiliki tingkat intoleransi peringkat pertama seIndonesia, tidak terjadi.

Komisioner Komnas HAM Jayadi Damanik menuturkan pada 2016 lalu pengaduan terkait pembatasan dan perusakan tempat ibadah mendominasi dengan 44 pengaduan sedangkan sisanya terkait pelarangan ibadah atau kegiatan keagamaan. Beberapa aduan yang datang dari Jawa Barat di antaranya permasalahan GKI Yasmin di Bogor, penyegelan tujuh gereja di Cianjur, Permasalahan HKBP Filadelfia Bekasi, permasalahan sejumlah gereja di Kota Bandung, hingga temuan pemerasan di sejumlah gereja di Jawa Barat. Selain itu, ada pula pelarangan aktivitas KKR di Bandung, serta permasalahan eks-anggota Gafatar dan Jamaah Ahmadiyah Indonesia di Jawa Barat (Pikiran Rakyat, 10 Januari 2017).

Ada beberapa praktik baik yang diperlihatkan oleh kepala daerah seperti di Bandung. Walikota Bandung menerbitkan dua izin gereja yang selama ini dipermasalahkan kemudian menjamin izin tersebut tidak akan dicabut meski ada desakan dari sebagian warga. Pemkot Bekasi yang mulai menyelesaikan permasalahan empat gereja yang sebelumnya ditolak sebagian warga hingga mempertahankan kebijakan pemberian IMB tersebut meski mendapat penolakan dari sejumlah Ormas di sana. Pemkot Bogor juga memberikan respons positif dengan mencari penyelesaian permanen terkait masalah GKI Yasmin yang sudah berlangsung sejak 2008 dengan menyodorkan ide "berbagi lahan". Meskipun awalnya mendapat penolakan, namun hingga saat ini gagasan tersebut mendapat sambutan positif dari seluruh pihak (Liputan6.com).

Perspektif interaksi simbolik berusaha memahami perilaku manusia dari sudut pandang subjek. Perspektif ini menyarankan bahwa perilaku manusia harus dilihat sebagai proses yang memungkinkan manusia membentuk dan mengatur perilaku mereka dengan mempertimbangkan ekspektasi orang lain yang menjadi mitra interaksi mereka.

Menurut pakar interaksi simbolik, kehidupan sosial pada dasarnya adalah “interaksi manusia dengan menggunakan simbol-simbol." Mereka tertarik pada cara manusia menggunakan simbol-simbol yang mempresentasikan apa yang mereka 
maksudkan untuk berkomunikasi dengan sesamanya, dan juga pengaruh yang ditimbulkan penafsiran atas simbol-simbol ini (Mulyana, 2008:60). Secara ringkas, Interaksionisme Simbolik didasarkan premis-premis berikut: Pertama, individu merespons suatu situasi simbolik. Mereka merespons lingkungan, termasuk objek fisik (benda) dan objek sosial (perilaku manusia) berdasarkan makna yang dikandung komponen-komponen lingkungan tersebut bagi mereka. Ketika mereka menghadapi suatu situasi, respons mereka tidak bersifat mekanis, tidak pula ditentukan oleh faktorfaktor eksternal. Respons mereka bergantung pada bagaimana mereka mendefinisikan situasi yang dihadapi dalam interaksi social. Kedua, makna adalah produk interaksi sosial, karena itu makna tidak melekat pada objek, melainkan dinegosiasikan melalui penggunaan bahasa. Negosiasi itu dimungkinkan karena manusia mampu menamai segala sesuatu, bukan hanya objek fisik, tindakan atau peristiwa namun juga gagasan yang abstrak (Mulyana, 2008: 71-72).

Ada tiga konsep penting yang dibahas dalam teori interaksi simbolik yaitu Pikiran (Mind), Diri (Self), dan Masyarakat (Society). Hal ini sesuai dengan hasil pemikiran George H. Mead yang dibukukan dengan judul Mind, Self, and Society. Dalam interaksi, manusia menafsirkan tindakan verbal dan nonverbal. Bagi Mead, tindakan verbal merupakan mekanisme utama manusia. Penggunaan bahasa atau isyarat simbolik oleh manusia dalam interaksi sosial mereka pada gilirannya memunculkan pikiran (mind) dan diri (self), seperti yang dikatakan Mead sendiri:

"Kemampuan menemukan makna ini dan menunjukkannya kepada orang lain dan kepada organisme adalah suatu kemampuan yang memberikan kekuatan unik kepada manusia. Kendali ini dimungkinkan oleh bahasa. Mekanisme kendali atas makna dalam arti inilah yang merupakan, menurut saya, apa yang kita sebut “pikiran"” (Mulyana, 2008: 83).

Teori interaksi simbolik menjelaskan bahwa pikiran mensyaratkan adanya masyarakat, dengan kata lain masyarakat harus lebih dulu ada, sebelum adanya pikiran. Dengan demikian, pikiran adalah bagian integral dari proses sosial bukan malah sebaliknya: proses sosial adalah produk pikiran. Seorang manusia yang sadar diri, tidak mungkin ada tanpa adanya kelompok sosial terlebih dahulu. Pikiran adalah mekanisme penunjukan diri (self-indication), untuk menunjukkan makna kepada diri sendiri dan kepada orang lain. Pikiran mengisyaratkan kapasitas dan sejauh mana manusia sadar akan diri sendiri mereka sendiri, siapa dan apa mereka, objek di sekitar mereka dan makna objek tersebut bagi mereka. Manusia menunjukkan objek yang mempunyai makna kepada diri mereka sendiri, seperti mereka menunjukkannya kepada orang lain. Manusia juga menunjukkan kepada diri mereka sendiri bahwa terdapat makhluk yang serupa dengan mereka yang dapat mereka nilai dalam komunikasi tatap muka (Mulyana, 2008: 84). 
Mead juga melihat (dalam Mulyana, 2008: 85) pikiran dengan cara yang pragmatik. Pikiran melibatkan proses berpikir yang diarahkan untuk memecahkan masalah. Dunia nyata penuh dengan masalah. Pikiran berusaha memecahkan masalahmasalah tersebut sehingga orang-orang dapat bekerja lebih efektif lagi di dunia.

Pada konteks ini, pandangan Mead sejajar dengan perspektif Schutz. Menurut Schutz, dalam menunjukkan makna objek, situasi, dan perilaku kepada diri sendiri dan kepada orang lain, individu harus menggunakan apa yang Schutz sebut pengkhasan (typication). Pengkhasan ini yang berasal dari persediaan pengetahuan individu yang terendapkan, digunakan untuk menandai individu manusia, motivasi manusia, tujuan, dan pola tindakan.

Inti dari teori interaksi simbolik adalah tentang "diri" (self) dari George Herbert Mead. Mead seperti juga Cooley menganggap bahwa konsepsi diri adalah suatu proses yang berasal dari interaksi sosial individu dengan orang lain. Diri tidak terlihat sebagai sesuatu yang berada dalam individu seperti aku atau kebutuhan yang teratur, motivasi dan norma serta nilai dari dalam. Diri adalah definisi yang diciptakan orang melalui interaksi dengan yang lainnya di tempat ia berada. Dalam mendefinisikan aku, manusia mencoba melihat dirinya sebagai orang lain, melihatnya dengan jalan menafsirkan tindakan dan isyarat yang diarahkan kepada mereka dan dengan jalan menempatkan dirinya dalam peranan orang lain (Moleong, 2005:22).

Pandangan Mead tentang diri terletak pada konsep "pengambilan peran orang lain" (taking the other role of other). Konsep Mead tentang diri merupakan penjabaran "diri sosial" yang dikemukakan William James dan pengembangan dari teori Cooley tentang diri. Bagi Mead dan pengikutnya, individu bersifat aktif, inovatif yang tidak saja tercipta secara sosial, namun juga menciptakan masyarakat baru yang perilakunya tidak dapat diramalkan. Dengan kata-kata Mary Jo Deegan yang menyatakan individu sendiri yang mengontrol tindakan dan perilakunya, dan mekanisme kontrol terletak pada makna yang dikontruksi secara sosial (Mulyana, 2008: 75).

Menurut Mead, sebagai suatu proses sosial, diri terdiri dari dua fase, yaitu "aku" (I) dan "daku" $(M e)$. Aku adalah diri yang subjektif, diri yang refleksif yang mendefinisikan situasi dan merupakan kecenderungan impulsif individu untuk bertindak dalam suatu cara yang tidak terorganisasikan, tidak terarah, dan spontan, sementara daku adalah pengambilan peran dan sikap orang lain, termasuk suatu kelompok tertentu (Mulyana, 2008:88).

Mead berargumen bahwa interaksi mengambil tempat di dalam sebuah struktur sosial yang dinamis-budaya, masyarakat dan sebagainya. Individu-individu lahir dalam konteks sosial yang sudah ada. Mead mendefinisikan masyarakat sebagai jejaring hubungan sosial yang diciptakan manusia. Individu-individu terlibat di dalam masyarakat melalui perilaku yang mereka pilih secara aktif dan sukarela. Jadi, masyarakat menggambarkan keterhubungan beberapa perangkat perilaku yang terus 
disesuaikan oleh individu-individu. Masyarakat ada sebelum individu tetapi diciptakan dan dibentuk oleh individu (Yasir, 2011:39).

\section{Metode}

Metode yang digunakan pada penelitian ini adalah kualitatif dengan pendekatan studi kasus. Penelitian kualitatif merupakan metode penelitian yang digunakan untuk meneliti pada kondisi yang alamiah. Pada tahap ini peneliti mendeskripsikan apa yang dilihat, didengar, dirasakan dan ditanyakan. Tahap selanjutnya yaitu reduksi atau fokus. Pada tahap ini peneliti mereduksi segala informasi yang telah diperoleh pada tahap pertama untuk memfokuskan pada masalah tertentu. Pada tahap reduksi ini, peneliti menyortir data dengan cara memilih mana data yang menarik, penting, berguna, dan baru.

Menurut Bogdan dan Taylor dalam buku Metodologi Penelitian Kualitatif karangan Prof. Dr. Lexy J. Moleong, M.A.A., metode penelitian kualitatif didefinisikan sebagai sebuah prosedur penelitian yang menghasilkan data deskriptif berupa kata-kata tertulis ataupun lisan dari orang orang dan perilaku yang dapat diamati. Menurut mereka, pendekatan ini diarahkan pada latar dan individu tersebut secara holistik (utuh). Jadi dalam hal ini tidak boleh mengisolasikan individu atau organisasi kedalam variabel atau hipotesis, tapi perlu memandangnya sebagai bagian dari suatu keutuhan (Bogdan dan Taylor dalam Moleong, 2004: 4).

Pendekatan penelitian studi kasus berupaya menelaah sebanyak mungkin data mengenai subjek yang diteliti (Yin, 2012 : 21). Studi kasus adalah suatu pendekatan mempelajari, menerangkan atau mengintepretasi suatu kasus dalam konteksnya secara natural tanpa adanya intervensi dari pihak luar. Inti studi kasus yaitu kecenderungan utama di antara semua ragam studi kasus bahwa studi kasus ini berusaha untuk menyoroti suatu keputusan mengapa keputusan itu diambil, bagaimana diterapkan dan apa hasilnya. Definisi secara lebih teknis diungkapkan oleh Yin (2012: 31) adalah : “ $A$ case study is an empirical inquiry that investigates a contemporary phenomenon within is real life context when the boundaries between phenomenon and context are not clearly evident and in which multiple of evidence are used"

Menurut Robert K. Yin, penelitian studi kasus ini ada tiga jenis yakni studi kasus eksploratori yaitu sebuah metode dalam studi kasus yang dipakai untuk memperoleh data atau informasi awal bagi peneliti sosial yang akan dilakukan. Sedangkan studi kasus eksplanatori yaitu kasus-kasus tertentu yang diteliti tujuannya untuk memberikan pengetahuan mengenai sebab akibat, dan yang terakhir studi kasus deskriptif tujuannya memberikan gambaran yang mendalam tentang sebuah kasus yang di dalamnya terdapat pemaparan dari konsep-kosep penelitian.

Sebagai salah satu metode penelitian kualitatif, Lincoln dan Guba (Mulyana, 2006: 201) mengemukakan beberapa karakteristik studi kasus yang dianggap sebagai kelebihan yaitu : 1) Studi kasus merupakan suatu sarana utama bagi penelitian yang 
unik karena dapat menyajikan pandangan subjek yang ingin diteliti; 2) Studi kasus menyajikan uraian menyeluruh yang mirip dengan apa yang dialami pembaca dalam kehidupan sehari hari; 3) Studi kasus merupakan sarana efektif untuk menunjukkan hubungan antara peneliti dengan responden; 4) Studi kasus memungkinkan pembaca untuk menemukan konsistensi internal yang tidak hanya merupakan konsistensi gaya dan konsistensi faktual tetapi juga kepercayaan; 5) Studi kasus memberikan uraian tebal yang diperlukan bagi penilaian transferability ; 6) Studi kasus terbuka bagi peneliti atas konteks yang turut berperan bagi pemaknaan atas fenomena dalam konteks tersebut.

\section{Hasil dan Pembahasan}

\section{Pandangan FKUB dan Perwakilan Umat Beragama tentang Toleransi}

FKUB memandang toleransi sangat diperlukan untuk kerukunan umat beragama, tidak hanya umat beragama saja tapi juga umat berbudaya. Karena jika berbicara tentang kerukunan dan toleransi tidak hanya terbatas pada adanya perbedaan agama saja, tetapi juga perbedaan kebudayaan juga, seperti yang disampaikan oleh Rafani selaku Ketua FKUB Provinsi Jawa Barat:

“Agama sumbernya adalah kitab suci, seperti umat Islam Al-Qur'an, Kristen Injil, dan sebagainya. Itu semua diakui. Keberagamaan manusia dalam berinteraksi lewat budaya. Keberagamaan tidak bisa lepas dari budaya. karena itulah dalam membangun kerukunan agama dan budaya harus bersinergi. Budaya itu adalah hasil ekspresi dari budi daya manusia, akal budi manusia. Dalam keberagamaan religiusitas manusia tidak bisa lepas dari ranah budaya" (Wawancara dengan Ketua FKUB Jawa Barat Rafani Ahyar, 2017, 22 Maret).

Agama dan budaya harus saling bersinergi satu sama lain guna mencapai kerukunan dalam kehidupan umat manusia. Hal inilah yang sebenarnya dijunjung tinggi di Jawa Barat. Di Jawa Barat sendiri mengembangkan kerukunan umat manusia selain dengan sisi religius atau secara teologi, tetapi juga dengan pendekatan kebudayaan. Sehingga, Jawa Barat terkenal dengan filosofinya yaitu Silih Asah, Silih Asih, silih Asuh.

“.....silih asah itu saling memajukan saling harmoni dan kerja sama, sedangkan silih asih saling mengasihi, silih asuh mengasuh saling mengayomi diprioritaskan relevan dengan agama." "Anggota DPR di Jawa Barat sebanyak 60\% adalah pendatang atau non-Jawa Barat. Bahwa orang Jawa Barat moderat, masyarakat siapapun pendatang selama tidak berbuat yang aneh-aneh, karena orang Jawa Barat moderat dan terbuka" (Wawancara dengan Ketua FKUB Jawa Barat Rafani Ahyar, 2017, 22 Maret).

Jawa Barat memiliki falsafah Silih Asah, Silih Asih dan Silih Asuh. Someah Hade Kasemah. Caina Herang Laukna Beunang. Karakter orang Sunda diam, dan cenderung 
menghindari konflik. Bahkan dengan sangat terbuka menerima pendatang. " Silih Asah, Silih Asih, Silih Asuh “, Silih asah itu saling memajukan saling harmoni dan kerja sama, sedangkan Silih Asih saling mengasihi, Silih Asuh mengasuh saling mengayomi diprioritaskan relevan dengan agama. Artinya ketika ada konflik, tokoh lintas agama akan duduk bersama segera menyelesaikan permasalahan itu.

Dari filosofi tersebut lahir falsafah Sunda lainnya yaitu Someah Hade Ka Semah. Berangkat dari saling memajukan, bekerja sama, saling mengasihi satu sama lain, dan saling mengayomi antarmasyarakatnya membuat karakter masyarakat Jawa Barat menjadi sangat ramah kepada para pendatang yang berbeda adat dan budaya, serta agama. Karakter inilah yang membedakan keramahan masyarakat Jawa Barat dengan daerah lain. Di Jawa Barat, masyarakat relatif rukun menerima pendatang, tidak melihat asal-usul etnik atau agama.

FKUB menciptakan harmoni dan kerukunan antarumat beragama dengan mengadakan dialog dan kegiatan diskusi lintas agama baik di tingkat tokoh agama dan di kalangan anak muda. Boleh dikatakan sebenarnya konflik agama di Jawa Barat tidak ada, melainkan konflik dengan Ahmadiyah.

Ahmadiyah bertentangan dengan Islam karena tidak ada Nabi setelah Nabi Muhammad. konflik pun lebih mengarah ke ranah kesenjangan ekonomi (Wawancara dengan Ketua FKUB Jawa Barat Rafani, 2017, 23 Maret).

Perwakilan tokoh Katolik, yaitu Djoko Santoso menyatakan pula bahwa Jawa Barat dicanangkan oleh umat Katolik sebagai "rumah bersama". Mereka menganggap tidak ada mayoritas dan minoritas di Jawa Barat. Umat Katolik senantiasa menjaga dan menghargai kearifan lokal. Di mana hidup di suatu tempat berarti harus hidup bersama.

"Bahkan kami cetuskan juga, untuk kehidupan di Jawa Barat untuk membangun toleransi tadi, umat Katolik mencanangkan diri, memproklamirkan diri bahwa Jawa Barat adalah rumah bersama. Jadi tidak ada mayoritas, minoritas, ini adalah rumah kita bersama. Kita menghargai budaya Jawa Barat ya. Kearifan lokal daripada Jawa Barat, itu segala macemnya kita hormati itu. Kita hidup di sini ya hidup bersama. Dengan menganut agama kita masing-masing tapi saling hormat menghormati" (Wawancara dengan Djoko Santoso perwakilan FKUB Jawa Barat dari Katolik, 2017, 22 Maret).

Toleransi menurut Rafani adalah tindakan saling memahami dan saling mengerti satu sama lain antarumat beragama. Dalam artian sebagai umat beragama tentunya setiap manusia harus meyakini ajaran agama yang dimilikinya (bagi yang beragama Islam) sebagai agama yang paling benar, tidak harus meyakini agama lain. Namun ia juga menyatakan bahwa ia harus mengakui adanya agama lain yang berbeda dengan yang ia imani sehingga harus muncul sikap saling menghormati bukan saling melibatkan diri satu sama lain dengan ajaran dan kegiatan agama lainnya. 
"Jadi toleransi itu wilayahnya dikaitkan dengan akidah dan ibadah, orang Kristen ke gereja silakan, Hindu mau ke pura ya monggo. Jangan seperti fenomena saat ini Natal bersama-sama, Idul Fitri dan Idul Adha agama lain seperti Kristen ikut berlebaran. Ini sudah mencampur adukkan, karena itu toleransi saling menghargai, saling menghormati bukan saling melibatkan diri” (Wawancara dengan Ketua FKUB Jawa Barat Rafani Ahyar, 2017, 22 Maret).

Pandangan serupa disampaikan oleh perwakilan dari agama Katolik, Djoko Santoso (Purn). Ia menyatakan bahwa toleransi adalah sikap saling menghargai dan saling menghormati satu sama lain terkait perbedaan agama. Namun menurutnya, toleransi jika berada dalam tataran keberagaman dan perbedaan adalah tataran dengan tingkatan paling awal. Hanya sebatas saling menghargai dan menghormati itu. Ia menyatakan bahwa tingkatan yang lebih tinggi daripada toleransi adalah bisa terjalinnya sebuah kerja sama untuk kehidupan sehari-hari.

"Toleransi itu kita saling menghargai, menghormati agama lain. Tapi kalo tatarannya, menurut saya tataran daripada toleransi adalah tataran paling rendah sebenarnya. Tataran awal ya. Tataran lebih meningkat lagi dari toleransi yang lebih bagus, kita bisa saling bekerja sama. Dari pengertian tadi (saling menghormati, menghargai) kemudian dengan adanya penghormatan itu kita bisa bangun kebersamaan. Untuk saling bekerja sama. Ini tingkatan lebih tinggi dari kehidupan sehari-hari" (Wawancara dengan Djoko Santosos FKUB perwakilan agama Katolik, 2017, 22 Maret).

Dari kedua pernyataan tersebut terlihat bahwa adanya kesamaan makna toleransi dari perwakilan agama Islam dan Katolik, yaitu saling menghormati dan saling menghargai satu sama lain dalam hal keagamaan. Pernyataan Djoko lebih mendetail terkait bekerja sama, yaitu bekerja sama yang bukan dalam pelibatan diri untuk merayakan keagamaan sakral, sebagaimana yang juga dinyatakan oleh Rafani. Bekerja sama di sini dalam koridor gotong royong dalam kehidupan sosial sehari-hari, bukan bekerja sama dalam ranah teologi.

"Kalo lebih tinggi lagi ya susah karena masuk ke dalam ranah teologi sudah. Ya ini kita sebagai awam melihat, kalo masuk ke ranah teologi tidak bisa ya, bisa saja tapi tidak semua orang paham. Tapi menurut saya cukup ya untuk sementara ini dalam kehidupan sehari-hari ya toleransi dan bekerja sama tadi" (Wawancara dengan Ketua FKUB Jawa Barat Rafani Ahyar, 2017, 22 Maret).

Menurut Djoko, sebuah toleransi ini kemudian menjadi sangat penting agar tetap menjaga keharmonisan kehidupan antarumat beragama. Ia menyatakan bahwa hal tersebut sangat penting dilakukan dan harus dilakukan. Kehidupan bertetangga adalah salah satu contoh yang ia berikan. Keharmonisan itu diciptakan agar kehidupan 
bertetangga juga nyaman tidak terjadi permusuhan. Bahkan ia sangat dekat dengan tetangga-tetangganya yang mayoritas muslim. Ia sendiri menceritakan bahwa kehidupan bertetangganya sangat baik dan harmonis, terutama saat ada tetangga muslim yang meninggal. Bahkan saat tetangga samping rumahnya meninggal, ia yang terlebih dahulu dihubungi oleh keluarga tetangganya tersebut dan memohon maaf apabila ada kesalahan yang dilakukan oleh almarhum tetangganya tersebut.

Jadi keharmonisan antarumat beragama akan tercipta dari masing-masing individu yang seharusnya memberikan sebuah tindakan toleransi tersebut yang senantiasa saling bekerja sama dalam kehidupan sehari-hari. Baik itu di lingkungan rumah tinggal, pekerjaan, lingkungan pendidikan, dan lain sebagainya.

Untuk kasus intoleransi yang terjadi di Jawa Barat, ternyata banyak hal yang peneliti temukan di lapangan berdasarkan wawancara dengan FKUB Jawa Barat. Sebenarnya, secara umum, masyarakat Jawa Barat memiliki kerukunan yang baik. Kerukunan masyarakat tinggi karena didorong oleh agama, falsafah, dan ketaatan pada pemerintah. Konflik yang terjadi sebenarnya dapat diselesaikan dengan baik oleh pemerintah. Namun media terlalu menyoroti kasus Gereja Yasmin di Bogor dan Filadelfia di Bekasi dengan membingkai isi berita.

"...Namun sekarang media sering mem-blow up dan mempelintir berita sehingga menjadi lebih panas.....Media sering mengangkat gereja Yasmin di Bogor dan gereja di Bekasi Piladelpia. Dua kasus diulang dan di genaralisir. Berita ini di ulang-ulang.“ (Wawancara dengan Ketua FKUB Jawa Barat Rafani Ahyar, 2017, 22 Maret).

Dengan demikian, konflik yang diangkat oleh media adalah kasus yang memang sudah lama terjadi. Konflik ini bermula dari adanya penolakan pembangunan rumah ibadah gereja Yasmin dan gereja Filadelfia karena adanya kecurangan atau manipulasi Kartu Tanda Penduduk (KTP). Untuk membangun sebuah rumah ibadah harus memiliki beberapa persyaratan, salah satunya adalah jumlah warga penganut agama yang akan mendirikan rumah ibadah.

"Ada 90 penganut. Umpama satu kampung Kristen mau bangun gereja ada tidak. Ada 60 yang mendukung, dari lintas agama. Artinya setuju ada gereja disitu dan di kumpulkan lewat KTP, dan dua-duanya yang 90 dan 60 dibuktikan dengan KTP dan betul-betul warga di situ. Dan ini sering menjadi masalah karena pembangunan gereja memanipulasi KTP. Ketika ditelusuri Yasmin mendapat ijin dari walikota, ada yang menggunakan KTP palsu, gereja Yasmin sudah keluar ijinnya. Dan digugat masyarakat karena KTP palsu" (Wawancara dengan Ketua FKUB Jawa Barat Rafani Ahyar, 2017, 22 Maret).

Akan tetapi, media ternyata memunculkan berita yang berbeda seperti apa yang dikatakan oleh Rafani. Ia mengatakan bahwa dalam pemberitaan yang muncul itu umat 
Islam dikatakan tidak mendukung pembangunan gereja-gereja tersebut. Umat Islam kemudian disebut tidak toleran dalam hal pembangunan rumah ibadah agama lain. Hal ini akhirnya membuat Jawa Barat menjadi provinsi paling tidak toleran. Padahal Jawa Barat adalah provinsi yang kerukunan antarumat beragamanya baik-baik saja.

Untuk kasus intoleransi ini sendiri, Djoko memberikan pandangan yang berbeda. Meski bukan dalam hal kasus gereja Yasmin dan gereja Filadelfia, ia sendiri mengalami kejadian serupa di kota Bandung tepatnya di daerah perbatasan. Akan ada pembangunan gereja Katolik agar tidak terjadi penumpukan umat di gereja tengah kota. Hal tersebut guna mempermudah para jemaat untuk beribadah. Namun ketika proses perizinan dan lain sebagainya ada upaya penolakan terhadap pembangunan gereja tersebut. Padahal secara persyaratan sudah tercukupi dan lengkap. Ia menyatakan ada oknum lain yang memperkeruh suasana.

"Kemudian lagi, kita mau mendirikan rumah ibadah, mendirikan rumah ibadah persyaratannya udah dipenuhi semuanya, warga di situ bagus kok, menyambut, boleh sesuai dengan peraturan bersama 2 menteri No 9 dan No 8 tahun 2006 tentang PBM itu sudah terpenuhi semua. Kebetulan, ada orang luar, oknum dari luar, ini yang sering terjadi demikian oknum dari luar yang masuk. Inilah yang diungkapkan oleh beberapa lembaga survei dianggap Jawa Barat intoleransi” (Wawancara dengan Djoko Santoso perwakilan FKUB Jawa Barat dari agama Katolik, 2017, 22 Maret).

Djoko pun menyampaikan hal serupa terkait dengan pemberitaan gereja Yasmin dan Gereja Filadelfia. Media terus-menerus memberitakan hal yang sama dan terus diulang-ulang. Sehingga membuat opini publik bahwa Jawa Barat adalah provinsi yang intoleran terhadap perbedaan agama.

\section{Makna Toleransi dalam Tataran Konsep dan Kajian Interaksi Simbolik}

Toleransi pada umumnya dapat diartikan sebagai pemberian kebebasan kepada sesama manusia untuk menjalankan keyakinannya atau mengatur hidupnya dan menentukan nasibnya masing-masing. Pengertian toleransi dalam Kamus Bahasa Indonesia berasal dari kata "toleran" yang berarti bersifat atau bersikap menenggang (menghargai, membiarkan, membolehkan) pendirian (pendapat, pandangan, kepercayaan, kebiasaan, kelakuan, dan sebagainya) yang berbeda atau bertentangan dengan pendirian sendiri. Sedangkan toleransi yaitu sifat atau sikap toleran, batas ukur untuk penambahan atau pengurangan yang masih diperbolehkan (Kamus Bahasa Indonesia, 2008:1538).

Memaknai toleransi dalam kehidupan bermasyarakat, harus dipahami terlebih dahulu unsur-unsur toleransi sebagai berikut: Pertama, memberikan kebebasan atau kemerdekaan. Ini artinya setiap manusia diberikan kebebasan untuk berbuat, bergerak maupun berkehendak menurut dirinya sendiri dan juga di dalam memilih suatu agama 
atau kepercayaan. Kedua, mengakui hak setiap orang. Ini adalah sikap mental yang mengakui hak setiap orang di dalam menentukan sikap perilaku dan nasibnya masingmasing, serta tidak melanggar hak orang lain. Ketiga, menghormati keyakinan orang lain. Tidak boleh ada orang atau golongan yang berkeras memaksakan kehendaknya sendiri kepada orang atau golongan lain. Keempat, sikap saling mengerti satu sama lain. Saling anti dan membenci, saling berebut pengaruh adalah salah satu akibat dari tidak adanya saling mengerti dan saling menghargai antara satu dengan yang lain (Abdullah, 2001: 23).

Giddens mengemukakan toleransi juga dapat dikatakan istilah pada konteks agama dan sosial budaya yang berarti sikap dan perbuatan yang melarang adanya diskriminasi terhadap golongan-golongan yang berbeda atau tidak dapat diterima oleh mayoritas pada suatu masyarakat. Misalnya toleransi beragama di mana penganut agama mayoritas dalam sebuah masyarakat mengizinkan keberadaan agama minoritas lainnya (Digdoyo, 2018: 47). Jadi, toleransi antarumat beragama berarti suatu sikap manusia sebagai umat yang beragama dan mempunyai keyakinan, untuk saling menghormati dan menghargai manusia yang beragama lain.

Dari hasil pemaparan sebelumnya, peneliti mendapatkan beberapa kata kunci terkait dengan toleransi. Menurut Rafani selaku ketua FKUB Jawa Barat menyatakan bahwa toleransi adalah saling mengerti dan memahami satu sama lain antarumat beragama, membiarkan orang lain beribadah sesuai dengan ajaran yang diyakininya. Hal serupa disampaikan oleh Djoko yang menyatakan bahwa toleransi adalah sikap saling menghargai agama lain. Namun ia lebih menjabarkan bahwa tataran toleransi adalah tataran awal dalam kehidupan antarumat beragama. Tataran yang berada di atasnya adalah setelah toleransi itu terbangun maka umat beragama bisa saling bekerja sama dalam kehidupan sosial sehari-hari.

Makna toleransi yang disampaikan tersebut sesuai dengan konsep toleransi yang sudah dinyatakan sebelumnya bahwa toleransi adalah sifat atau sikap menenggang (menghargai, membiarkan, membolehkan) pendirian (pendapat, pandangan, kepercayaan, kebiasaan, kelakuan, dan sebagainya) yang berbeda dengan pendirian yang dimiliki oleh seseorang.

Pandangan FKUB tersebut mencerminkan pengamalan UU No 39 tahun 1999 tentang Hak Asasi Manusia. Undang-undang tersebut menjelaskan bahwa Negara Republik Indonesia mengakui dan menjunjung tinggi hak asasi manusia dan kebebasan dasar manusia sebagai yang secara kodrati melekat pada dan tidak terpisahkan dari diri manusia yang harus dilindungi, dihormati, dan ditegakkan demi peningkatan martabat beragama dan keyakinan.

Selain itu, Djoko pun menyebutkan bahwa tataran tinggi dari toleransi adalah adanya sikap bekerja sama antarumat beragama dalam kehidupan sehari-hari sosial mereka. Hal tersebut juga dijelaskan pada PBM (Peraturan Bersama Menteri) No 8 dan 9 tahun 2006 menegaskan tentang kerukunan umat beragama yang merupakan keadaan 
di mana hubungan sesama umat beragama yang dilandasi toleransi, saling pengertian, saling menghormati, menghargai kesetaraan dalam pengamalan ajaran agamanya dan kerja sama dalam kehidupan bermasyarakat, berbangsa dan bernegara di dalam Negara Kesatuan Republik Indonesia berdasarkan Pancasila dan UUD 1945.

Seperti telah disinggung di atas, untuk mencairkan kebekuan yang terjadi antarumat beragama, alternatif yang bisa dikemukakan adalah dengan mekanisme dialog keagamaan atau yang dikenal pula dengan istilah dialog antariman. Dialog antarumat beragama ini diperkirakan bisa mengantarkan para pemeluk agama pada satu corak kehidupan yang inklusif dan terbuka. Dialog diharapkan akan membawa umat beragama pada konsep unity in diversity dengan didasari corak pemikiran teologi plural.

Penelitian ini dikaji lebih mendalam dengan pendekatan teori Interaksi Simbolik. Masyarakat terdiri atas individu-individu. Mead berbicara mengenai dua bagian penting masyarakat yang mempengaruhi pikiran dan diri. Pemikiran Mead mengenai orang lain secara khusus (particular others) merujuk pada individu-individu dalam masyarakat yang signifikan bagi kita. Orang-orang ini biasanya adalah anggota keluarga, teman, dan kolega di tempat kerja serta supervisor. Kita melihat orang lain secara khusus tersebut mendapatkan rasa penerimaan sosial dan rasa mengenai diri. Identitas orang lain secara khusus dan konteksnya mempengaruhi perasaan akan penerimaan sosial kita dan rasa mengenai diri kita. Sering kali pengharapan dari beberapa particular others mengalami konflik dengan orang lainnya (West dan Turner, 2008:108).

Orang lain secara umum (generalized other) merujuk pada cara pandang dari sebuah kelompok sosial atau budaya sebagai suatu keseluruhan. Hal ini diberikan oleh masyarakat kepada kita, dan sikap dari orang lain secara umum adalah sikap dari keseluruhan komunitas. Orang lain secara umum memberikan informasi mengenai peranan, aturan, dan sikap yang dimiliki bersama oleh komunitas. Orang lain secara umum juga memberikan kita perasaan mengenai bagaimana orang lain bereaksi kepada kita dan harapan sosial secara umum. Perasaan ini berpengaruh dalam mengembangkan kesadaran sosial. Orang lain secara umum dapat membantu dalam menengahi konflik yang dimunculkan oleh kelompok-kelompok orang lain secara khusus yang berkonflik (West dan Turner, 2008:108).

Masyarakat memandang suatu realitas tidak serta-merta dalam pembentuk struktur aktualisasi, akan tetapi proses ini terlihat dan terbentuk dari setiap pembentuk kepribadian dalam individu yang terlalu terstruktur. Problematika ini cenderung berada pada tahap di mana aspek-aspek krusial yang menjadi generalized other. Hal ini mengantarkan pada pandangan masyarakat tentang benang merah yang membentuk sebuah kelompok sosial atau budaya. Pemberitaan yang terjadi dengan konflik yang membentuk setiap pandangan masyarakat tentunya memberikan aspek-aspek yang tidak terpisahkan dari struktur sosial tersebut, terlihat seperti pada pemikiran Mead yang memandang bahwa masyarakat (society) memiliki proses yang cukup besar dalam melihat persoalan. 
Persoalan ini cenderung berdiri pada titik pandangan dari FKUB yang tentunya sedikit mengadopsi pemikiran dari Mead tentang aspek (society). Aspek masyarakat ini mampu membentuk satu pandangan yang tentunya harus memiliki landasan konseptual dan pandangan pengalaman berdasarkan pemberitaan yang ditampilkan oleh media. Pemberitaan tersebut tentunya mampu membentuk pandangan yang baik secara positif maupun secara negatif. FKUB sebagai wadah dialog antarumat beragama memiliki peran dalam memberikan pemahaman dan pandangan terkait konflik yang terjadi di Jawa Barat tentang isu intoleransi di Jawa Barat. Hal semacam ini tentunya harus didampingi oleh tokoh-tokoh masyarakat dalam memberikan edukasi tentang pentingnya harmonisasi dan estetika dalam saling berhubungan.

Proses yang paling mendalam dalam membina adalah proses dari konstruksi realitas, pandangan ini hadir dalam konsep masyarakat yang dikemukakan oleh Mead. Beberapa hal yang menjadi karakteristik dari masalah ini adalah hal-hal yang mampu menimbulkan konflik. Ini terlihat dari beberapa faktor penyebab yang cenderung dinamis bergantung bagaimana para tokoh-tokoh ini membentuk pendekatan emosional dalam melihat persoalan-persoalan seperti ini. Faktor-faktor ini tentunya merujuk atau mengarah pada aspek-aspek mind, self dan society. Tahap inilah yang mampu ditunjukkan oleh teori ini sebagai esensi yang sangat bermanfaat untuk keberlangsungan dan harmonisasi.

Konflik-konflik yang terjadi sejatinya merupakan persoalan kompleks yang melibatkan berbagai dimensi kehidupan. Secara teori, konflik merupakan identitas perubahan dalam struktur evolusi, juga disebut anak tangga pertama yang dilalui untuk sebuah perubahan sosial. Perbincangan konflik agama dapat dilihat dari berbagai teori sosial, namun penulis mencoba melihatnya dari sisi teori Interaksi Simbolik. Teori ini berakar dan berfokus pada kajian bahwa hakikat kehidupan manusia adalah makhluk relasional yang memiliki daya untuk mempertimbangkan. Setiap individu pasti terlibat relasi dan berinteraksi dengan sesama.

Manusia muncul dalam dan melalui interaksi dengan yang di luar dirinya. Artinya, selain melakukan suatu interaksi intrapribadi, manusia juga melakukan kegiatan antarpribadi. Interaksi itu sendiri membutuhkan simbol-simbol tertentu. Simbol itu biasanya disepakati bersama dalam skala kecil maupun skala besar. Simbol dalam komunikasi dapat berupa bahasa ( $\mathrm{ral}$ ), tulisan, dan simbol lainnya yang dipakai dan bersifat dinamis, dapat berkembang dan memunculkan simbol-simbol baru, unik dan dimengerti bersama.

Keunikan dan dinamika simbol dalam proses interaksi sosial menuntut manusia harus lebih kritis, peka, aktif dan kreatif dalam menginterpretasikan simbol-simbol yang muncul dalam interaksi sosial. Hal tersebut dimaksudkan karena tidak semua simbol memiliki interpretasi yang sama.

Jika dikaitkan dengan persoalan agama, ada interpretasi yang berlaku hanya kepada satu kelompok saja, maka anggapan benar menjadi hal yang eksklusif. 
Interaksionisme Simbolik mengajarkan pentingnya memahami pemaknaan lain selain dari yang kita maknai secara pribadi, sehingga dapat terjalin komunikasi yang efisien dan harmonis. Penafsiran yang tepat atas simbol tersebut turut menentukan arah perkembangan manusia dan lingkungan. Sebaliknya, penafsiran yang keliru atas simbol dapat menjadi petaka bagi hidup manusia dan lingkungannya.

Kerukunan hidup umat beragama merupakan suatu sarana yang penting dalam menjamin integrasi nasional, maupun kehidupan dalam sehari-hari sekaligus merupakan kebutuhan dalam rangka menciptakan stabilitas yang diperlukan bagi proses pencapaian masyarakat Indonesia yang bersatu dan damai. Kerja sama yang rukun dapat terjadi apabila di antara para pemeluk agama merasa saling membutuhkan, saling menghargai perbedaan, saling tolong menolong, saling membantu dan mampu menyatukan pendapat atau istilah lainnya memiliki sikap toleransi.

\section{Faktor Penyebab Konflik}

Konflik yang terjadi pada kasus penolakan gereja Yasmin dan Gereja Filadelfia adalah karena adanya kecurangan dan manipulasi Kartu Tanda Penduduk. Kita ketahui bahwa untuk mendirikan rumah ibadah di suatu lingkungan ada syarat dan ketentuannya yaitu sebagai berikut: 1) Ada 90 orang penganut agama tertentu (yang diakui oleh Negara); 2) Ada 60 orang yang mendukung, dari lintas agama yang dibuktikan dengan kebenaran KTP bahwa orang-orang tersebut tinggal di daerah itu.

Pada kasus Gereja Yasmin dan Filadelfia yang terjadi adalah bukan penolakan dalam artian tidak boleh ada rumah ibadah agama lain di daerah tersebut bagi minoritas. Ketika diselidiki, setelah izin dari wali kota keluar baru ditemukan bukti bahwa adanya KTP palsu dan KTP yang menunjukkan bahwa beberapa orang penganut Kristen Protestan tersebut bukan warga setempat. Hal inilah yang menimbulkan konflik. Ini bukan berbicara pada ranah kemanusiaan yang tidak memberikan hak asasinya untuk beribadah. Akan tetapi lebih berbicara pada ketentuan birokrasi dan juga legalisasi terkait dengan persyaratan yang sudah ditentukan oleh pemerintah.

Adanya pelanggaran inilah yang kemudian menjadi konflik di lingkungan pendirian gereja Yasmin dan Filadelfia. Hingga saat ini, ketua FKUB Jawa Barat pun menyatakan bahwa kasus itu sudah teratasi sebenarnya. Hanya saja media tidak mengikuti kelanjutan kasus ini sehingga jika ada kasus intoleransi, kasus ini akan diangkat lagi oleh media seperti sebelumnya.

\section{Simpulan}

Kerukunan umat beragama adalah keadaan hubungan sesama umat beragama yang dilandasi toleransi, saling pengertian, saling menghormati, menghargai kesataraan dalam pengamalan ajaran agamanya dan kerja sama dalam kehidupan bermasyarakat, berbangsa, dan bernegara di dalam Negara Kesatuan Republik Indonesia berdasarkan 
Pancasila dan Undang-Undang Dasar Negara Republik Indonesia tahun 1945 (PBM No.8 dan 9 tahun 2006).

Permasalahan yang terjadi di Provinsi Jawa Barat adalah adanya kesalahpahaman dan kecurangan dalam mendirikan rumah ibadah. Masyarakat Jawa Barat memiliki falsafah kerukunan yaitu Someah Hade kasemah, Caina herang laukna benang, Silih Asah Silih Asih Silih Asuh. Masalah GKI Yasmin yang berlangsung sejak 2008, pemerintah telah menyodorkan ide "berbagi lahan". Meskipun awalnya mendapat penolakan, namun hingga saat ini gagasan tersebut mendapat sambutan positif dari seluruh pihak.

Konflik yang terjadi pada kasus penolakan pendirian gereja Yasmin dan Gereja Filadelfia adalah karena adanya kecurangan dan manipulasi Kartu Tanda Penduduk. Dalam pendirian rumah ibadah di suatu lingkungan ada syarat dan ketentuannya yaitu sebagai berikut: Ada 90 orang penganut agama tertentu (yang diakui oleh negara), ada 60 orang yang mendukung dari lintas agama yang dibuktikan dengan kebenaran KTP bahwa orang-orang tersebut tinggal di daerah itu.

Kasus Gereja Yasmin dan Filadelfia bukan penolakan, dalam artian bukan tidak boleh ada rumah ibadah agama lain di suatu daerah tersebut yang minoritas. Permasalahan yang terjadi di lapangan adalah setelah izin dari Wali Kota keluar baru ditemukan bukti adanya KTP palsu dan KTP yang menunjukkan beberapa orang penganut agama Kristen Protestan tersebut bukan warga setempat. Inilah yang menjadi sumber konflik, bukan pada perihal ranah kemanusiaan yang tidak memberikan hak asasinya untuk beribadah. Namun, lebih berbicara pada ketentuan birokrasi dan juga legalisasi terkait persyaratan yang sudah ditentukan oleh pemerintah. Adanya pelanggaran inilah yang kemudian menjadi konflik di lingkungan pendirian gereja Yasmin dan Filadelfia. Ketua FKUB Jawa Barat menyatakan bahwa kasus itu sudah teratasi.

\section{Referensi}

Abdullah, M. (2001). Pluralisme Agama dan Kerukunan dalam Keagamaan. Jakarta: Kompas.

Asshiddiqie, J. (2014, Februari). Toleransi dan Intoleransi Beragama di Indonesia Pasca Reformasi. Makalah disampaikan pada Dialog Kebangsaan Ormas Gerakan Masyarakat Penerus Bung Karno di Hotel Borobudur, Jakarta.

Digdoyo, E. (2018). Kajian Isu Toleransi Beragama, Budaya, Dan Tanggung Jawab Sosial Media. JPK: Jurnal Pancasila dan Kewarganegaraan, Vol. 3, No. 1, Januari 2018 ISSN 2527-7057 (Electronic), ISSN 2545-2683 (Print). 42-60.

Haryanto, A. (2016, Oktober 3) Jawa Barat Tempati Provinsi dengan Kasus Intoleransi Tertinggi. tirto.id Diperoleh dari, https://tirto.id/bQBYhttps://tirto.id/Jawa Barat-tempati-provinsi-dengan-kasusintoleransi-tertinggi-bQBY 
. (2016, Oktober 3). Riset Sebutkan Kasus Intoleransi Terbanyak di Jawa

Barat. Antara Diperoleh dari, https://www.antaranews.com/berita/588044/risetsebutkan-kasus-intoleransi-terbanyak-di-Jawa Barat

Irfan, M. (2017, Desember 28) Jawa Barat Masih Jadi Provinsi Paling Intoleran. Pikiran Rakyat, Diperoleh dari, https://www.pikiranrakyat.com/nasional/2017/01/10/Jawa Barat-masih-jadi-provinsi-paling-intoleran390238

Moleong, J. L. (2004). Metedologi Penelitian Kualitatif. Bandung: Remaja Rosdakarya. Mulyana, D. (2008). Metode Penelitian Kualitatif. Bandung: Remaja Rosdakarya . (2006). Metode Penelitian Kualitatif. Bandung: Remaja Rosdakarya

Nisvilyah, L. (2013).Toleransi Antarumat Beragama Dalam Memperkokoh Persatuan Dan Kesatuan Bangsa (Studi Kasus Umat Islam Dan Kristen Dusun Segaran Kecamatan Dlanggu Kabupaten Mojokerto). Jurnal Kajian Moral dan Kewarganegaraan Vol. 3, No. 1, Januari 2018, 382-396.

Nugroho, A. (2016, Desember 28) Konflik Kebebasan Beragama Tertinggi di Jawa Barat, Kok Bisa? Liputan 6.com Diperoleh dari, https://www.liputan6.com/regional/read/2689917/konflik-kebebasan-beragamatertinggi-di-jawa-barat-kok-bisa

Peraturan Bersama Menteri. (2006). Peraturan Bersama Menteri (PBM) No 8 dan 9

Prayitno, P. (2016, Agustus 10) Survei: Jawa Barat 'Juara' Kasus Intoleransi di Indonesia Liputan 6.com dari, https://www.liputan6.com/regional/read/2573619/survei-jawa-barat-juara-kasusintoleransi-di-indonesia

West, R. \& Turner, L. H. (2008). Pengantar Teori Komunikasi: Analisis dan Aplikasi, Edisi 3, Buku 1, terj. Maria Natalia Damayanti Maer. Jakarta: Salemba Humanika. Yasir. (2011). Teori Komunikasi. Pekanbaru: Pusbangdik.

Yin. R. K. (2012). Studi Kasus : Desain \& Metode.Jakarta : PT Raja Grafindo Persada. 